UDK $630 * 52 / 56: 528.8(234.422$ Igman)

\title{
ESTIMATION OF WOOD PRODUCTION SPATIAL DISTRIBUTION IN THE HIGH FOREST ON IGMAN MOUNTAIN
}

\author{
Procjena prostornog rasporeda drvne produkcije u visokim šumama na Igmanu \\ Azra L̦abaravdil ${ }^{1}$, Besim Balil ${ }^{1}$, Merisa Osmanovil ${ }^{2}$, Admir Avdagil ${ }^{2}$
}

\begin{abstract}
Information about quantitative and qualitative forest attributes are the base for successful forest planning and management. Forest inventories collect number of data used for different estimations from large (management unit level) to small (forest stand) scales. Then, control sampling has to be done in order to confirm regularity of terrestrial work. Such sample becomes data source too. Recent approach for forest characterization includes all available information as sources for additional nonstandard insight. Here were used available data about wood volume and increment from control sample for high forest on mountain Igman. Also, recent Landsat TM image from vegetation period was available and used in this research. Here is applied $\mathrm{k}$ nearest neighborôs estimation method. Five nearest neighbors and Euclidian distance is chosen for estimation and mapping. Biases for all forest attributes were nonsignificant. Obtain results show non significant differences between means and observed and estimated distributions of wood volume and increment. It is estimated higher mean wood volume and increment of broadleaves while means for conifers and totals are lower. That higher wood volume and increment is estimated in all diameter classes for broadleaves while lower quantities are estimated for conifers. Spatial mapping presents distribution of wood volume and increment respecting variability of vegetation in high forest on Igman.
\end{abstract}

Key words: wood volume and increment, inventory control sample, Landsat TM, $k-N N$ estimates, spatial mapping.

\section{INTRODUCTION - Uvod}

Regular forest inventory as a base for forest management collects huge number of data and information related with different types (environmental, forest

\footnotetext{
${ }^{1}$ Cooresponding author: azrac2012@ gmail.com, Faculty forestry University Sarajevo
} 
production and structure, other). Beside, recent potentials related to technological possibilities supported research of integration all available data in nature monitoring. Remote sensing became one of additional source of information with confirmed contributio to forest management. So, potentials of integration all available resources as forest field data, satellite image spectral data, technical and human resources for spatial mapping of the most important forest attributes become challenge. Integral approach has been present in forest inventories as on large scale so for small area in many countries (Finland, Norway, Sweden, United States) (KaTILA I TOMPPO, 2001; Tompro I Halme, 2004; Franco-Lopez et al., 2001; McRoberts et al., 2002; HAAPANEN ET AL., 2004) researches that integrate terrestrial and spectral data in forest attributes estimation have been conducted in Bosnia and Herzegovina ( $L$ ABARAVDIĹ ET AL., 2011, 2012, 2014; MAHMUTOVIĹ ET AL., 2013).

Intensive field measurement in regular forest inventories on the forest management unit level collects number data and information. Beside, the obligation for controlling accuracy of the forest inventory preformed as additional terrestrial measurement collects data using control sample. Control sample tries to cover variability of forest attributes and structures ensuring performance with the high quality.

In this paper, potentials of terrestrial data from control sample and available Landsat TM spectral data are used for spatial non-parametrical estimation and mapping of wood volume and increment in the high forest on the Igman mountain.

\section{MATERIALS AND RESEARCH METHODS - Materijal i metod istraživanja}

The study area is situated in the central, mountainous part of Bosnia and Herzegovina. The research area represents the high forests on Igman mountain which are integral part of Management unit ñIgmanò in wider Forest management area "Igmansko".

High forests here are consisted of the mixed fir (Abies alba), spruce (Picea abies) and beech (Fagus sylvatica) stands manly. Also, here appears Scots pine (Pinus sylvestris), Sessile oak (Quercus petraea), Hornbeam (Carpinus betulus), Maple (Acer sp.) and other species_occasionally. On the area of Management unit "Igman" are dominated karst forms that are typical for limestone. The climate is specific for confrontation valley modified - continental climate, which with increasing altitude exceeds in the alpine climate type. Mountain climate is represented on the most of the northern part of the area. The terrain is very permeable, so that the management unit is sparce hydrologically. The basic substrate of the management unit is a simple structure, consisting of limestone and dolomites of the Mesozoic age.

For this research, data were collected in uneven aged forest stands with beech, fir and spruce in different mixture combination. Control sample was designed as selection of four random samples in one forest department (Figure 1). Sampling plan 
was based on systematic quadratic grid with random start. Point sampling used adapted concentric circles, which radius depending on trees diameter (Lojo, 2012).

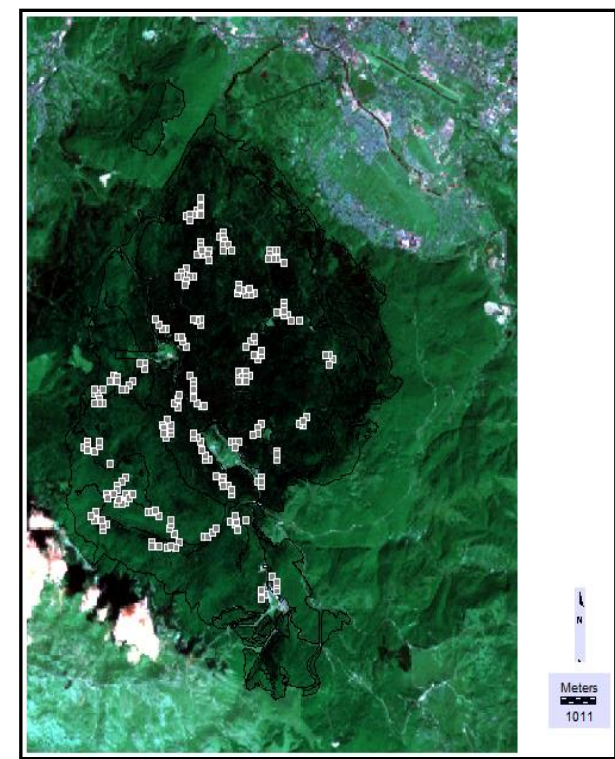

Figure 1. Sampling sheme (Landsat 753) Slika 1. Shema uzorka (Landsat 753)
Size of border radius of concentric circles is in connection with the corresponding diameter classes (NFI methodology). On the field were set a systematic grid of concentric circles with equal distance between centres of circles. Size of systematic grid was $100 \mathrm{~m}$ between sample centres. Systematic grid was set that cover all research area (inventory sample). On every sample plot was collect a general information as sample number, department number, coordinates, type of sample (detail or regular), canopy, diameter of selected trees, tree species etc. On every fourth sample plot (detailed one, $25 \%$ of samples), additional information were collected as: tree height, quality classes, diameter increment (in past 10 years), damages on trees and infections of trees.

Descriptive statistics of wood volume $\left(\mathrm{m}^{3} / \mathrm{ha}\right)$ and increment $\left(\mathrm{m}^{3} / \mathrm{ha}\right)$ per diameter classes and total from field sample is presented in table 1.

Table 1. Descriptive statistics for wood volume and increment per diamteter classes Tabela 1. Deskriptivna statistika za sveukupnu drvnu masu i prirast po debljinskim stepenima

\begin{tabular}{|c|c|c|c|c|c|c|c|c|c|}
\hline & & & $5-10$ & $10-20$ & $20-30$ & $30-50$ & $50-80$ & $>80$ & Total \\
\hline \multirow{6}{*}{ 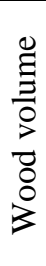 } & \multirow{2}{*}{ Broadl. } & Mean & 3.69 & 7.25 & 8.47 & 35.09 & 20.87 & 0.3 & 75.67 \\
\hline & & S.D. & 9.93 & 20.1 & 24.59 & 85.28 & 52.8 & 4.48 & 125.87 \\
\hline & \multirow{2}{*}{ Conif. } & Mean & 3.91 & 19.15 & 38.51 & 128.74 & 139.64 & 1.68 & 331.64 \\
\hline & & S.D. & 9.08 & 27.89 & 53.77 & 120.31 & 128.5 & 9.11 & 180.97 \\
\hline & \multirow{2}{*}{ Total } & Mean & 7.6 & 26.4 & 46.98 & 163.83 & 160.52 & 1.98 & 407.31 \\
\hline & & S.D. & 13.3 & 32.25 & 56.53 & 133.22 & 140.39 & 10.1 & 181.26 \\
\hline \multirow{6}{*}{ 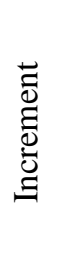 } & \multirow{2}{*}{ Broadl. } & Mean & 0.07 & 0.1 & 0.1 & 0.24 & 0.11 & 0 & 0.65 \\
\hline & & S.D. & 0.34 & 0.41 & 0.5 & 0.97 & 0.52 & 0 & 1.93 \\
\hline & \multirow{2}{*}{ Conif. } & Mean & 0.1 & 0.4 & 0.64 & 1.32 & 1.03 & 0.01 & 3.43 \\
\hline & & S.D. & 0.42 & 1.2 & 1.51 & 2.42 & 1.84 & 0.08 & 4.86 \\
\hline & \multirow{2}{*}{ Total } & Mean & 0.18 & 0.5 & 0.69 & 1.53 & 1.09 & 0.01 & 3.64 \\
\hline & & S.D. & 0.57 & 1.28 & 1.42 & 2.53 & 1.89 & 0.08 & 5.15 \\
\hline
\end{tabular}


The Landsat TM satellite image acquired on 27. 08. 2011 (path 187, row 30) was downloaded from the internet (http://glovis.usgs.gov/) and projected in national coordinate system for this research. Digital values of seven bands (band $1 \mathrm{i}$ blue, band $2 \ddot{i}$ green, band $3 \ddot{i}$ red, band $4 \ddot{i}$ near infrared, band $5 \ddot{i}$ shortwave ir-1, band $6 \ddot{i}$ thermal IR, band $7 \ddot{i}$ shortwave IR-2) were reclassified on 20-meter spatial resolution, histogram equalized and then used as input spectral data.

Here are used statistical parametrical and non-parametrical methods. Sample data and estimates are analyzed using descriptive statistic, correlation, nonparametrical regression and hypothesis testing ( $\mathrm{t}$ test, KS - Kolmogorov-Smirnov test). Spatial mapping is generated using non-parametrical $\mathrm{k}$ nearest neighborô method $(\mathrm{k}$ $\mathrm{NN}$ ). Estimates for wood volume and increment are based on sample data from field (control sample) and satellite image digital values. The $\mathrm{k} \mathrm{NN}$ estimates are generated using Forest K-NN software. Detailed description of applied method and procedure is given in Chirici et al. 2008, 2012.

\section{RESULTS AND DISCUSION - Rezultati i diskusija}

Spatial distributions of wood volume and increment potentials on Igman mountain are affected with specific environmental conditions and forest management regimes. It is known that the highest wood volume and increment appears on mountain plateau in mixed fir/spruce/beech stand but their spatial distributions have not been examined yet. In order to analyze those distributions in forest classification unit related to high forest dominated on the research area here is used available control sample consisted of 228 sample plots distributed randomly (Figure 1.). The main goal of control sample was to check accuracy estimates in regular forest inventory. Statistical hypothesis testing confirmed equality of wood volume and increment averages obtained in regular and control samples. Descriptive statistics shows dominance of conifers in wood volume and increment consistently. Obtained high variability for both forest attributes and categories pointed out spatial heterogeneity. It is known that dominant wood volume is situated on mountain moderate plateau so significant correlations (bolded values) between forest attributes per groups (conifers and broadleaves) and spectral responses of six bands (B2 to B7) are determined (Table 2).

Table 2. Correlation matrix

Tabela 2. Korelaciona matrica

\begin{tabular}{|c|l|r|r|r|r|r|r|r|}
\cline { 3 - 9 } \multicolumn{2}{c|}{} & \multicolumn{1}{c|}{ B1 } & \multicolumn{1}{c|}{ B2 } & \multicolumn{1}{c|}{ B3 } & \multicolumn{1}{c|}{ B4 } & \multicolumn{1}{c|}{ B5 } & \multicolumn{1}{c|}{ B6 } & \multicolumn{1}{c|}{ B7 } \\
\hline \multirow{2}{*}{$\begin{array}{c}\text { Wood } \\
\text { volume } \\
\left(\mathrm{m}^{3} / \text { ha }\right)\end{array}$} & Total & -0.04 & 0.02 & -0.02 & -0.01 & 0.02 & -0.06 & 0.03 \\
\cline { 2 - 9 } & Conifers & -0.11 & $\mathbf{- 0 . 1 8}$ & $\mathbf{- 0 . 2 2}$ & $\mathbf{- 0 . 4 1}$ & $\mathbf{- 0 . 3 7}$ & $\mathbf{0 . 2 4}$ & $\mathbf{- 0 . 3 3}$ \\
\cline { 2 - 9 } & Broadleaves & 0.10 & $\mathbf{0 . 2 8}$ & $\mathbf{0 . 2 9}$ & $\mathbf{0 . 5 7}$ & $\mathbf{0 . 5 6}$ & $\mathbf{- 0 . 4 3}$ & $\mathbf{0 . 5 2}$ \\
\hline \multirow{3}{*}{$\begin{array}{c}\text { Increment } \\
\left(\mathrm{m}^{3} / \mathrm{ha}\right)\end{array}$} & Total & 0.02 & -0.02 & -0.01 & -0.03 & -0.05 & 0.15 & -0.07 \\
\cline { 2 - 9 } & Conifers & -0.05 & $\mathbf{- 0 . 1 8}$ & -0.15 & $\mathbf{- 0 . 3 2}$ & $\mathbf{- 0 . 3 3}$ & $\mathbf{0 . 3 4}$ & $\mathbf{- 0 . 3 1}$ \\
\cline { 2 - 9 } & Broadleaves & 0.14 & $\mathbf{0 . 3 0}$ & $\mathbf{0 . 2 5}$ & $\mathbf{0 . 5 0}$ & $\mathbf{0 . 5 0}$ & $\mathbf{- 0 . 3 3}$ & $\mathbf{0 . 4 2}$ \\
\hline
\end{tabular}


In order to identify the configuration for $\mathrm{k} \mathrm{NN}$ estimations, several configurations related to distances (Euclidian, Mahalanobis, fuzzy) and number of nearest neighbours are analyzed. It is found that the Euclidian distance and five nearest neighbours gives acceptable results on pixel level. No significant differences for biases for all diameter classes were obtained for all categories (conifers, broadleaves, total) and both attributes (wood volume and increment). Higher Root Mean Square Errors (RMSE) are identified in diameter class $30 \mathrm{~cm}$ to $50 \mathrm{~cm}$ (Table 3.). Analysis showed the highest variability in the same diameter class in sample data. Also several geo-positions of relevant plots affected non-consistent estimates here.

Table 3. RMSE for wood volume and increment Tabela 3. RMSE za sveukupnu drvnu masu i prirast

\begin{tabular}{|c|c|c|c|c|c|c|}
\cline { 2 - 7 } \multicolumn{3}{|c|}{} & \multicolumn{3}{|c|}{ Wood volume } & \multicolumn{3}{c|}{ Increment } \\
\hline & Conifers & Broadleaves & TOTAL & Conifers & Broadleaves & TOTAL \\
\hline $5-10$ & 1.42 & 1.38 & 1.96 & 0.07 & 0.05 & 0.09 \\
\hline $10-20$ & 4.32 & 2.51 & 4.62 & 0.17 & 0.05 & 0.18 \\
\hline $20-30$ & 8.33 & 2.92 & 8.64 & 0.21 & 0.06 & 0.20 \\
\hline $30-50$ & 29.20 & 9.12 & 28.47 & 0.54 & 0.12 & 0.55 \\
\hline $50-80$ & 17.14 & 7.57 & 19.71 & 0.25 & 0.07 & 0.26 \\
\hline$>80$ & 1.14 & 0.34 & 1.19 & 0.01 & 0.00 & 0.00 \\
\hline Total & 29.26 & 14.50 & 28.83 & 0.92 & 0.24 & 0.95 \\
\hline
\end{tabular}

Spatially - based estimates for wood volume and increment are obtained per diameter classes and total. Hypotheses about mean differences (t test) showed that there are no significant differences for wood volume and increment in all categories (Table 4). Also, Kolmogorov Smirnov test resulted with non significant differences between distributions for both attributes and categories too (Table 4).

Table 4. Comparation of means (t test) and distribution (KS test)

Tabela 4. Poređenje prosjeka ( $t$ test) i raspodjela (KS test)

\begin{tabular}{|c|l|c|c|c|c|}
\cline { 3 - 6 } \multicolumn{2}{c|}{} & $|\mathrm{t}|$ & $\mathrm{P}$ (sig. > 0.05) & KS & $\mathrm{P}($ sig > 0.05) \\
\hline \multirow{2}{*}{$\begin{array}{c}\text { Wood } \\
\text { volume } \\
\left(\mathrm{m}^{3} / \mathrm{ha}\right)\end{array}$} & Total & 0.01 & 0.99 & 0.58 & 0.89 \\
\cline { 2 - 6 } & Conifers & 0.09 & 0.92 & 0.29 & 0.99 \\
\cline { 2 - 6 } & Broadleaves & 0.35 & 0.74 & 0.58 & 0.89 \\
\hline \multirow{3}{*}{$\begin{array}{c}\text { Increment } \\
\left(\mathrm{m}^{3} / \mathrm{ha}\right)\end{array}$} & Total & 0.04 & 0.97 & 0.29 & 0.99 \\
\cline { 2 - 6 } & Conifers & 0.10 & 0.92 & 0.29 & 0.99 \\
\cline { 2 - 6 } & Broadlleaves & 0.50 & 0.62 & 0.86 & 0.99 \\
\hline
\end{tabular}


Diameter distributions of wood volume for sample data and area-based estimates per broadleaves and conifers are given in Figure 2.

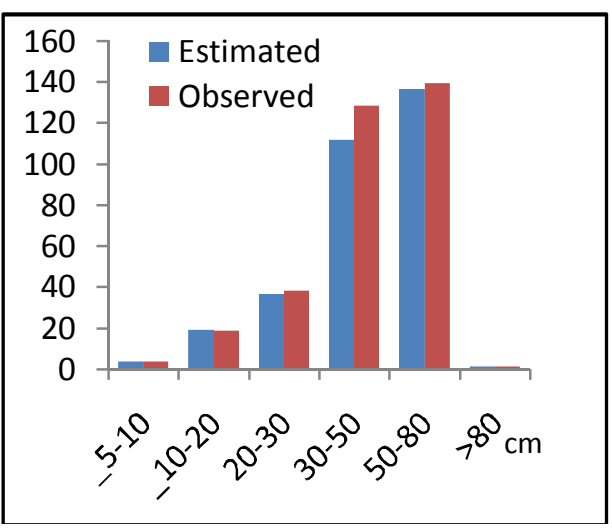

a) Conifers

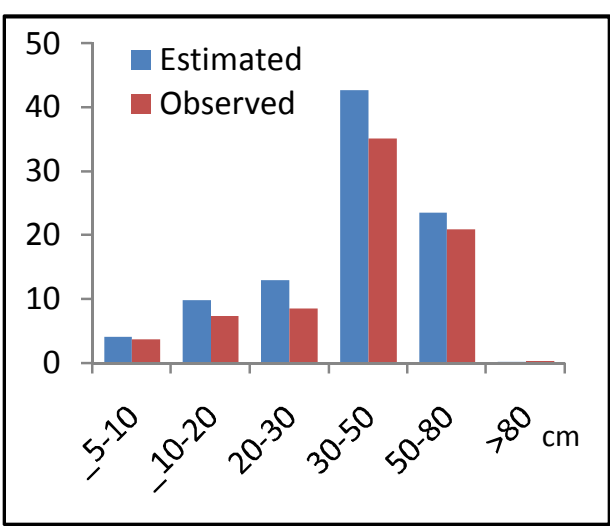

b) Broadleaves

Figure 2. Diameter distribution of wood volume $\left(\mathrm{m}^{3} / \mathrm{ha}\right)$

Slika 2. Debljinska raspodjela sveukupne drvne mase $\left(\mathrm{m}^{3} / \mathrm{ha}\right)$

Difference in diameter distribution for both groups is obtained. Also, differences are obtained for groupôs increments. Estimates for broadleves are slightly higher then in the sample.

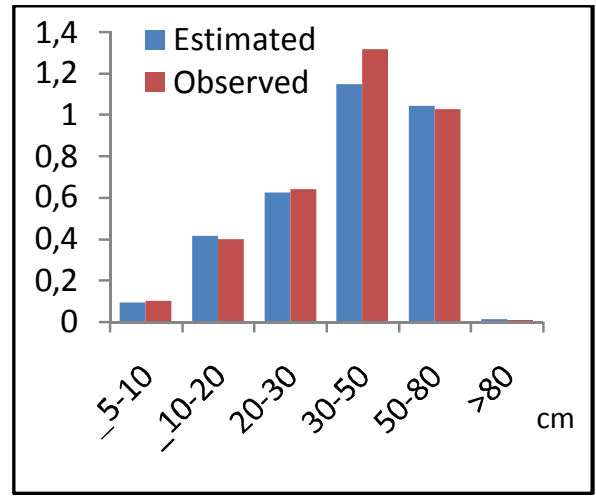

a) Conifers

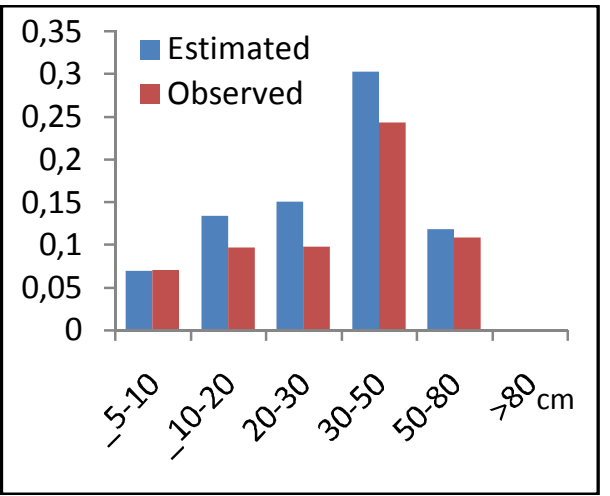

b) Broadleaves

Figure 3. Diameter distribution of increment $\left(\mathrm{m}^{3} / \mathrm{ha}\right)$

Slika 3. Debljinska raspodjela prirasta $\left(\mathrm{m}^{3} / \mathrm{ha}\right)$

It is visible that wood volume estimation is slightly higher for broadleaves then in the sample. 


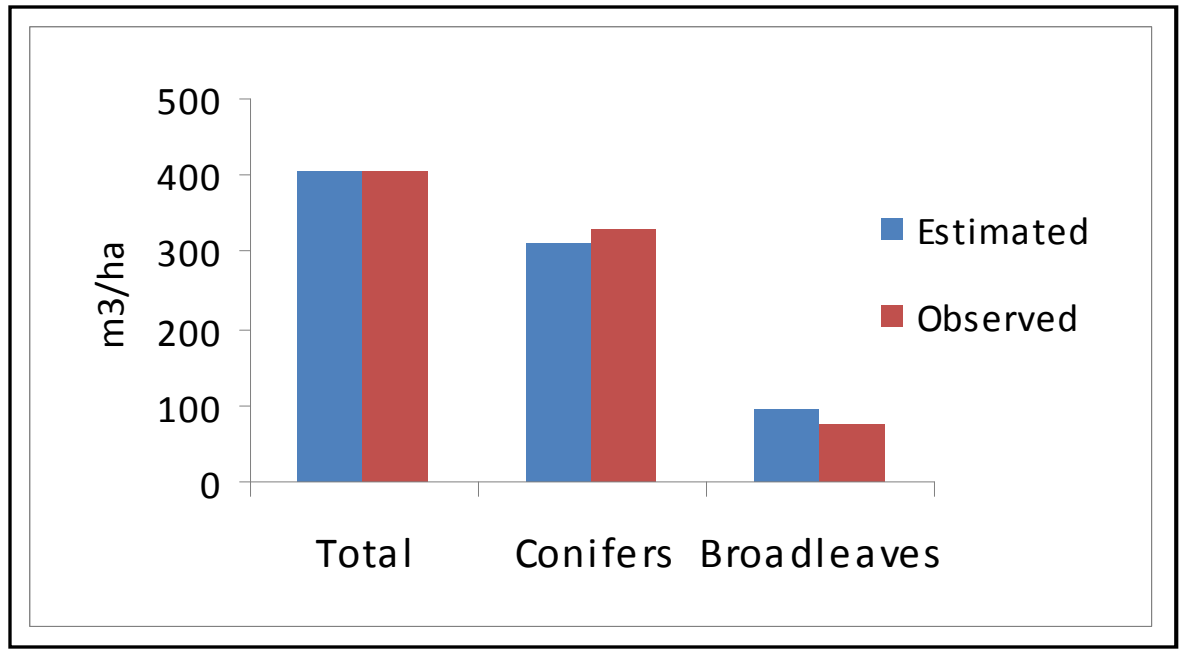

Figure 4. The average wood volume per groups and total Slika 4. Prosjeci sveukupne drvne mase po grupama i ukupno

The following graph compares the average wood volume increment based on spatial-based estimation and sample.

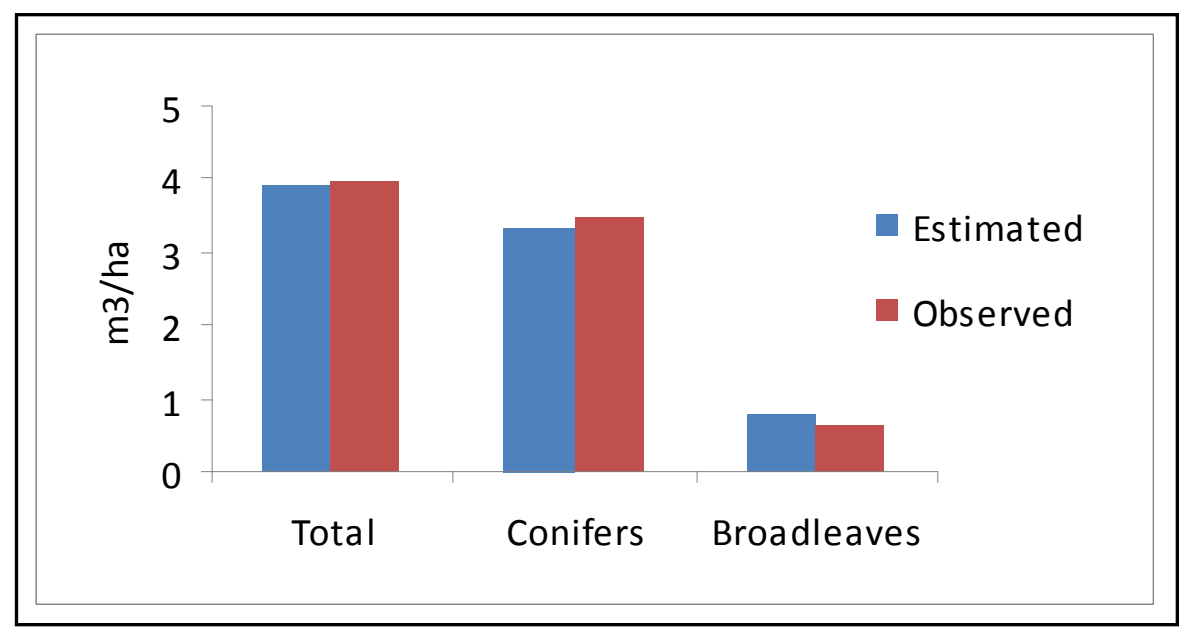

Figure 5. The average increment per groups and total Slika 5. Prosjeci prirasta po grupama i ukupno

Increments based on spatially distributed estimates are consistent with wood volume: higher increment is found for broadleaves while estimated increment for conifers and total is lower then in the sample. 
Spatial k NN estimates generated data for spatial distribution mapping for wood volume and increment per groups and total (Figure 7 and 8).

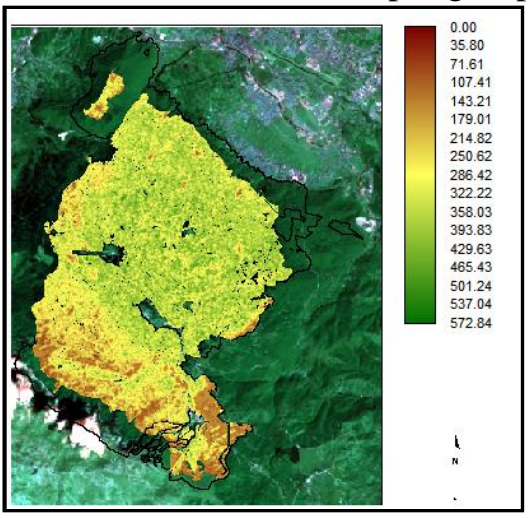

a) Conifers

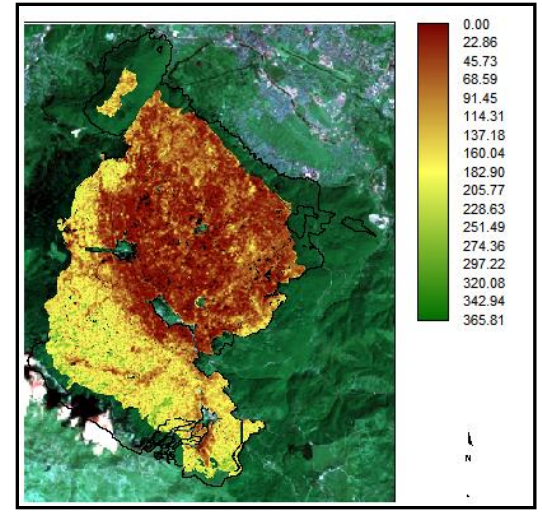

b) Broadleaves

Figure 6. Spatial distribution of wood volume per groups

Slika 6. Prostorni raspored sveukupne drvne mase po grupama

On Figure 6 are presented spatial distributions of wood volume for conifers and broadleaves. It can be concluded that most wood volume of conifers in area which cover a mixed forest of fir, spruce and beech, and less in the area which cover a subalpine beech (a). On the other side most of wood volume of broadleaves is in area that cover subalpine beech and less in area that cover mixed forest (b).

Also the similar conclusion can be made for increment of conifers and broadleaves (Figure 7). Most of increment of conifers is in tested area which covers mixed forest of fir, spruce and beech, and less of increment of conifers are in tested area which cover subalpine beech (a).

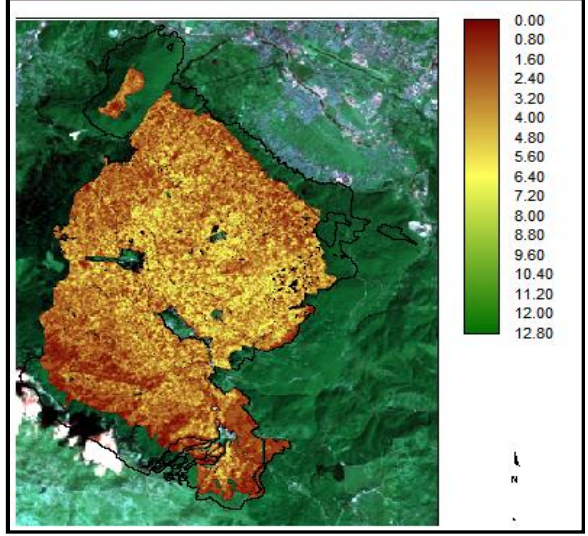

a) Conifers

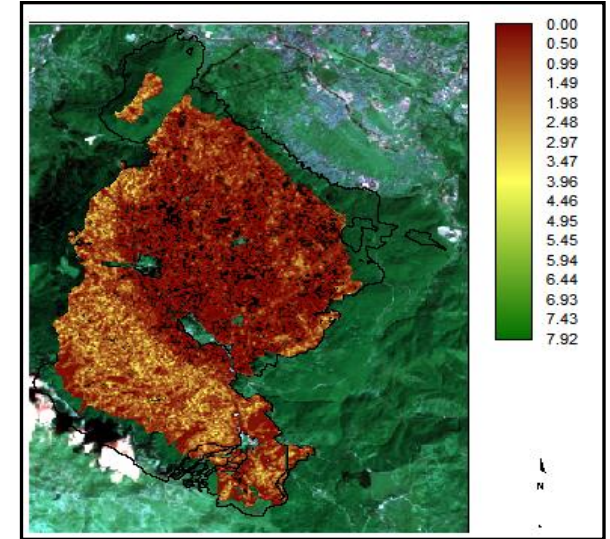

b) Broadleaves

Figure 7. Spatial distribution of increment per groups Slika 7. Prostorni raspored prirasta po grupama 
Most of increment of broadleaves is in tested area which is covered by subalpine beech and less in area which are covered by mixed forest of fir, spruce and beech (b).

\section{CONCLUSION - Zaključci}

This research evaluates application of non-parametrical k-NN method for spatial distribution estimates of wood volume on increment in high forest in central Bosnia using inventory control sample data and Landsat TM spectral data.

Provided estimates for mean wood volume and increment on pixel level and thematic mapping are consistent with control sample and knowledge of forest spatial variability on test area. Also, statistical analysis shows non existence of significant differences between observed and estimates mean values of wood volume and increment on the pixel level. Then, percentage distributions of forest attributes point out higher wood volume for broadleaves and lower for conifers then estimated from sample in all diameter classes. Reasons for obtained differences could be related to control sample itself, higher non-covered natural variability and/or influential environmental characteristics that affect estimates. So, these findings should be examined on the whole inventory sample.

It could be emphasized that the $\mathrm{k} \mathrm{NN}$ based thematic mapping gives realistic insight in spatial distribution of wood volume and increment on Igman plateau. So, this alternative approach may provide new aspect of wood production analysis.

The research may serve as a basis for further more detailed estimation based on full inventory sample and other available information (digital elevation model, vegetation index, soil types, and topographic maps). Further research should be conducted to cover whole management unit with different forest types, development stage and management regimes. Also, more detailed satellite data could be included in consideration.

\section{REFERENCES - Literatura}

Chirici G., Corona P., Marchetti M., Mastronardi A., Maselli F., Bottal L., TRAVAGLINI D. (2012): K-NN FOREST. User's guide and tutorial. Available online at www.forestlab.net.

Chirici, G., A. Barbati, P. Corona, M. Marchetti, D. Travaglini, F. Maselli, and R. BERTINI. 2008. Non-parametric and parametric methods using satellite images for estimating growing stock volume in Alpine and Mediterranean forest ecosystems. Remote Sensing of Environment 112(5):2686-2700. 
Labaravdil A., Pelz R. D., Chirici G., Kutzer Ch., Ĺatí́ E., Delíl H. (2011): Weighted functions in the $k$-NN estimates of growing stock in high forest in Bosnia. Works of Faculty Forestry University of Sarajevo. Vol 2. p. 15-29.

Ĺabaravdí́ A., Trétilí T., Mujezinoví́ O. (2012): Procjena prostorne rasprostranjenosti oǵteĺ enja ġıma na bazi daljinske detekcije. ANU BiH. Nau! na konferencija ĠME $̈$ İ INDIKATOR KVALITETA OKOLIĠA. Zbornik radova.

labaravdí́ A., lojo A., Balí́ B., Osmanoviĺ M., Avdagiĺ A., Mahmutoviĺ G. (2014): Procjena gumskih drvnih zaliha unsko-sanskog podrulja na bazi taksacionih snimanja druge nacionalne inventure gima i IRS satelitskih snimaka/Growing stock estimation of productive forest in unsko-sansko area based on the $2^{\text {nd }}$ national forest inventory field data and IRS satellite images. Naǵe gume/Our forests. $\mathrm{N}^{\mathrm{o}}$ 32-33, str. 4-11.

L ABARAVDí́ A. (2007): Efficient Estimation of Forest Attributes with k NN. Ph.D. thesis, Faculty of Forest and Environmental Sciences, Albert-Ludwigs-Universität Freiburg im Breisgau, Germany.

Forest management plan for the Forest management area "Igmansko".

FRANCO ï LOPEZ, H., A. R. EK, AND M. E. BAUER. (2001): Estimation and mapping of forest stand density, volume and cover type using k-nearest neighbors method. Remote Sensing of Environment, 77: 251-274.

Hatapanen, R., Ek., R., A., Bauer, E., M., Finle, O., A. (2004): Delineation of forest/nonforest land use classes using nearest neighbour methods. Remote Sens. Environ., 89: 265-271.

Katila, M., TOMPPo, E. (2001): Selecting estimation parameters for the Finnish multisource National Forest Inventory. Remote Sensing of Environment, 76: 1632.

LoJo., A. (2012): Metodika rada pri izradi ġmskogospodarskih osnova za Ġumsko gospodarska podrul ja u Kantonu Sarajevo. Izvjeğaj projekta.

MahmutoviĹ G., ĹABARAVdí́ A., Osmanoví́ M. (2013): Procjena drvnih zaliha na bazi Landsat TM+ snimka na gimovitom miniranom podrulju GJ Majevica ï Jablanil ka rijeka/Growing stock estimation based on the Landsat $\mathrm{TM}+$ on forested mined area of Majevica ï Jablanil ka rijeka. Naǵe gime/Our forest. $\mathrm{N}^{\mathrm{o}}$ 30-31, XII godina, str. 13-20.

McRoberts, R., Nelson, M. D., Wendt, D. G. (2002): Stratified Estimation of forest Area using Satellite imagery, Inventory Data and the k-nearest neighbors technique. Remote Sensing of Environment, 82: 457-468.

TOMPPO, E., HALME, M. (2004): Using coarse scale forest variables as ancillary information and weighting of variables in k-NN estimation: a genetic algorithm approach. Remote Sensing of Environment 92. 


\section{SAŽETAK}

Poznavanje karakteristika ġumske drvne produkcije predstavlja osnovu za uspjeg̉no planiranje gazdovanja ġmama. Redovnim inventurama ġma prikupljaju se brojni podaci i informacije na bazi kojih se procjenjuje stanje gimskih resursa $\mathrm{u}$ kvantitativnom i kvalitativnom pogledu. Kontrola tal nosti taksacionih snimanja provodi se kroz ponovljena snimanja na kontrolnom uzorku koji takoLe treba da reprezentuje stanje gimskih resursa. U tom smislu kontrolni uzorak moǵe posluğiti kao materijal za istraǵivanje stanja ǵma posebno u dijelu istraǵvanja novih procedura procjena kakvo je preduzeto u ovom radu. Cilj ovog istraǵivanja je bio ispitati efikasnost procjene prostornog rasporeda sveukupne drvne mase i njenog prirasta $u$ visokim gumama na bazi terenskih snimanja kontolnog uzorka i spektralnih podataka dostupnog Landsat satelitskog snimka.

Kao podrul je istraǵivanja su odabrane visoke ġıme u Gospodarskoj jedinici Igman ĠGP Igmansko. Materijal za istraǵivanje !̣inile su lokalne procjene sveukupne drvne mase i njenog prirasta kontrolnog uzorka i spektralni podaci Landsat TM satelitskog snimka. Primjenjen je neparametrijski k NN metod procjene i evaluirana njegova tal nost.

Osnovni rezultati do kojih se dog̉o ukazuju na efikasne procjene sveukupne drvne mase i prirasta na nivou pixela kao i na podrulju visokih ġma. Poredjenje sveukupne drvne mase i prirasta po debljinskim stepenima rezultiralo je procjenom veĺ e mase I prirasta liǵ ara a manje ḷ etinara u svim debljinskim stepenima. Takodje su procjenjeni manji prosjeci sveukupne drvne mase i prirasta za liǵ are i l etinare zbirno.

Procjene su predol ene na tematskim kartama prostornog rasporeda sveukupne drvne mase i prirasta koje vizueliziraju kvantitete gimske drvne produkcije na Igmanu.

Rezultati istraǵvanja ukazuju na potencijal ovog pristupa u analizi ġımskih resursa te se preporul uju dalja istraǵivanja zasnovana na uzroku taksacionih snimanja regularne inventure ġma, satelitskih snimaka visoke rezolucije i drugih dostupnih relevantnih informacija (digitalni model terena, pedologka karta, vegetacijski indexi i druge). 